\title{
The Argus PA-200 Projector
}

\author{
By Amando R. Boncales and Rebecca P. Butler, Northern Illinois University
}

$\mathbf{P}$ rojectors and cameras have a long history, from rudimentary pinhole cameras (O'Connor \& Robertson, 2002) to the "Magic Lantern," considered by many to be the ancestor of modern projectors and cameras (Pfragner, 1974). In the United States, educational technology as a field grew during World War II, a time when projectors and training films gained prominence in preparing military personnel (Sattler, 1990).

The Argus PA-200 Projector was produced after the war, 1949-1957, by the Argus Company. At the time, it was considered a modern miniature projector for showing $35 \mathrm{~mm}$ slides, Bantam (828) transparencies, and film strips where extra brilliance was required. The manual instructed users in the following manner: "To use it for a slide projection, place it on a table or other stable support. Adjust the distance between the projector and the screen to achieve the desired picture sizes. As its name suggests, the PA-200 incorporates all of the success and popular features which have made Argus Projector the most popular in the photographic imaging industry" (Argus, 1949, p 1-2).
By the late 1950's, intense competition from foreign manufacturers offering better features at lower prices, was causing financial stress to Argus. In 1957, Argus was purchased by Sylvania Electric Products Co., and in 1959, Sylvania was acquired by GTE. Then in the early 1960s, Argus's new corporate owners essentially dumped the company onto Mansfield Industriesa Chicago photographic distributor and a much smaller company. By 1963, camera and projector production had stopped. Starting in 1967, Argus's corporate ownership turned over several more times, with the brand popping up in various guises. The era of USdesigned and manufactured cameras had ended (Gabino, 2005).

\section{References}

Ann Arbor Area Crappy Camera Club. (n.d.). Retrieved from http://www.crappycameraclub.org/argus-museum-show.html

Argus, Inc. (1949). Argus PA-200 Projector. Ann Arbor, Michigan.

camera-wiki.org. (n.d.). Argus. Retrieved from http://camera-wiki.org/wiki/Argus crappycameraclub.org

Gabino, H.J. (2005). Argomania: A look at Argus cameras and the company that made them. Doylestown, Pennsylvania: Aeone Communications.

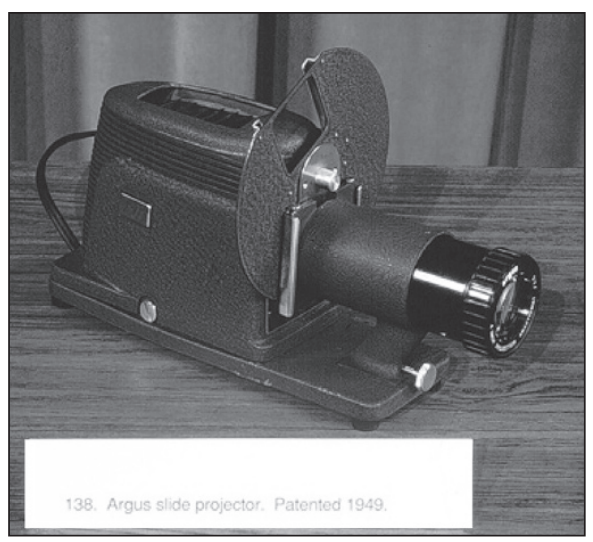

Lee and Lida Cochran AECT Archives,

Blackwell Museum of Education

Northern Illinois University, 1999

Kuzyk, H. (2006). "An Outstanding book about Argus Cameras and the company behind them." Retrieved from http:// www.amazon.com/Argomania-LookArgus-Cameras-Company/productreviews/097705070X

Lee and Lida Cochran AECT Archives. (1999). Kodak Senior Six-20 Camera. DeKalb, Illinois: Blackwell Museum of Education, Northern Illinois University. Retrieved from http://www.cedu.niu. edu/blackwell/multimedia/high/library. html

Michigan in pictures. (2007). The Argus Camera Company of Ann Arbor, Michigan. Retrieved from http://michpics.wordpress.com/2007/03/29/the-argus-camera-company-of-ann-arbor-michigan/

O'Connor, J.J. and Robertson, E.F. (2002).

"Light through the ages: Ancient Greece to Maxwell." Light in the quantum era. Retrieved from http://www-groups. dcs.st-and.ac.uk/ history/HistTopics/ Light_1.html

Pfragner, J. (1974). The motion picture: from magic lantern to sound film. Folkestone, England: Bailey and Swinfen.

Saettler, P. (1990). The Evolution of American educational technology. Englewood, Colorado: Libraries Unlimited. 